Original Research Paper

\title{
The Influence of Bioecological Factors on the Development of the Bracon during Breeding under Laboratory Conditions
}

\author{
${ }^{1,2}$ Karlygash Alpysbayeva, ${ }^{2}$ Ainur Alimbekova, ${ }^{1}$ Ainura Adilkhankyzy and ${ }^{3}$ Abai Sagitov \\ ${ }^{1}$ Kazakh Research Institute for Plant Protection and Quarantine Named after Zh. Zhiembaev, Almaty, Kazakhstan \\ ${ }^{2}$ Kazakh National Agrarian University, Almaty, Kazakhstan \\ 3"Agropark Ontustik" LLP, Almaty, Kazakhstan
}

\author{
Article history \\ Received: 19-11-2020 \\ Revised: 02-03-2021 \\ Accepted: 05-03-2021 \\ Corresponding Author: \\ Karlygash Alpysbayeva \\ Kazakh Research Institute for \\ Plant Protection and \\ Quarantine Named after Zh. \\ Zhiembaev, Almaty, \\ Kazakhstan \\ Email: erke07naz05@mail.ru
}

\begin{abstract}
In the presented work, the authors investigated the development and sex ratio of the Bracon in various environmental conditions. The greater Galleria mellonella was used as the host of the entomophage under laboratory conditions. The authors studied the influence of the temperature environment, additional imaginal nutrition and the age of the host on the sex ratio of the Bracon. Experiments with testing the effect of different temperatures in the process of infecting a host with a parasite on the sex ratio of the entomophage showed that with an increase in the temperature of parental individuals from 25 to $30^{\circ} \mathrm{C}$, not only fertility increased but also the number of emerged Bracon imagines. With an increase in the temperature at which the parental pairs were kept up to $35^{\circ} \mathrm{C}$, there was no increase, but, on the contrary, a slight decrease in the emerged wasps was observed. Testing of different feeding options showed that feed different in quality composition had different effects on fertility and sex ratio in the offspring. High fertility was obtained in the experiments using honey and sugar solutions for additional imaginal nutrition. The highest number of females was also obtained by feeding parental pairs with a $20 \%$ solution of honey $(67.2 \%)$ and sugar syrup $(64.5 \%)$.
\end{abstract}

Keywords: Biological Method, Entomophage, Plant Protection, Galleria mellonella, Helicoverpa armigera

\section{Introduction}

The global trend in the development of research on plant protection, at present, is based on the rejection of the use of highly toxic pesticides and focusing on the use of environmentally friendly technologies, the main of biogenic means of protection (FiBL, 2015; FiBL IFOAM, 2015; Svechnikova, 2019).

Agriculture is one of the industries with the highest anthropogenic pressure (Lamberth et al., 2013; Rogozin and Beketova, 2018). Soil pollution with chemicals causes significant damage to the environment (Lysov, 2010). About 2 million tons of pesticides are using annually in the world. Their remains are found in $40 \%$ of the studied samples of grain, berries, fruits and vegetables. Many chemical pesticides have already been used as biological weapons and the possibility of such use in the future is not excluded (Svechnikova, 2019; Lamberth et al., 2013; Rogozin and Beketova, 2018; Lysov, 2010).

The intensification of agriculture around the world, including on the territory of Kazakhstan, has become an extremely urgent economic issue at the national and international levels. The problem of protecting crops and crops from pests plays an important role in intensifying agriculture (Nagibina, 2014; Zhuchenko, 2012). The use of an integrated plant protection system employing biological agents and bioinsecticides is one of the solutions to these problems. It deserves more and more attention as an alternative to chemical methods with the hope of replacing the chemical products completely (Monastyrskii, 2006).

One of the main components of the biological method of plant protection is the use of entomophages against insect pests. However, this method of plant protection has not yet fully developed in Kazakhstan (Toleubayev et al., 2011). The biological method will allow preserving entomophages and pollinating insects; this makes it possible to save money and get an environmentally friendly product. Since the number of entomophages in natural agrobiocenoses of cotton is not sufficient to suppress the main pests, artificial reproduction of entomophages has great prospects (Ismukhambetov, 2011; Sagitov, 2011). 
Helicoverpa Armigera Hbn. is the most harmful of all Lepidoptera pests of cotton and the Bracon (Bracon hebetor Say, 1836) is an effective parasite of Helicoverpa armigera. It also readily infects marbled clover and clover cutworm, silver Y, beet armyworm, hollyhock seed moth, cotton boll moth, etc.

Today, in the south of the country, there are eight bio laboratories and three biofactories for breeding beneficial insects against pests of the cotton plant, of which only the Zhetysay biofactory (Kazakhstan, Turkestan region) conducts entomophagous breeding on a mechanized line. In 2017 alone, the use of the Bracon in general against three generations of the pest amounted to 98 thousand ha (Toleubayev, 2009).

In connection with the importance and versatility of the beneficial activity of the Bracon, further increasing the efficiency of its use as a parasite of insect pests is a promising direction in agriculture. In this regard, the study of the problem of optimizing the ecological parameters of the life support of the Bracon for obtaining a viable and active offspring used as a means of combating harmful insects is of considerable scientific and practical interest.

Thus, according to some researchers (Kovalenkov et al., 2016; Drozda and Zagaiko, 2016), environmental factors are among the most important conditions for the formation of the economically useful function of the Bracon, which consists in the destruction of caterpillars of harmful insect species.

Bracon hebetor Say belongs to the Braconidae family and the order of Hymenoptera insects. It is widely distributed in the European part of the CIS (from the North to St. Petersburg), in the Caucasus and the republics of Central Asia. The Bracon, like other species of the Braconidae genus, is mostly confined to the steppe, forest-steppe and desert zones (Narzikulov, 1982). In the steppe and forest-steppe zones, they concentrate on forest edges, in depressions and flood plains of rivers. In the desert zone, their main habitats are flood plains, oases and areas with shrubby vegetation and in the forest zone, the Bracon prefer open dry stations. In natural conditions, adults are inactive. In search of their prey, they flutter over the plants. In hot weather, they prefer to hide behind bracts, sepals, inside capsules, or behind the wrapper of corn cobs and inside damaged tomato fruits. Fertilized females hibernate in twisted, not fallen leaves of poplar, fruit and other trees, as well as in forked branches, hollows, bark cracks, near cotton and other crops. With the onset of warm days, usually, in April or May, overwintered individuals leave their wintering places and begin to feed on the nectar of flowering plants, mainly of the families of Umbelliferae, milkweed and legumes. Besides, they feed on the hemolymph of their victims after their paralysis and the sweet secretions of aphids and scale insects. The development of the Bracon takes place on the caterpillars of the older host. During the season, the number of generations reaches 6-7 (Ovorov et al., 2013; Kimsanboev et al., 2013).

Wide ecological plasticity makes it possible to breed the Bracon in artificial conditions without any particular difficulties. The cultivation of phytophagous insects, including the hosts of the Bracon in artificial conditions, imposes several requirements, including the use of feed which is relatively simple in composition and preparation, but at the same time, fully meets the nutritional needs of the insects. For the Bracon, such hosts are the caterpillars of many barn pests, as well as beekeeping pests. The most studied hosts for the Bracon are the caterpillars of the greater Galleria mellonella and Ephestia kuehniella.

Under laboratory conditions, the Bracon are collected for subsequent release into nature on crops infected with the pest, mainly at the imago stage, but sometimes at the pupal stage. The collection of the parasite, at the imago stage, is more efficient, since it is based on the biological feature of the Bracon, namely positive phototropism (Bogatyrev and Agas'yeva, 2019; Sharmagii, 2019).

With mass rearing of the parasite under laboratory conditions, adults fly from the dark zone to the light zone on their own accord. Thus, for example, they fly from the darkened area of the camera to the light (illuminated) screen (Chanda and Chakravorty, 2000) or from the dark chamber to the light chamber (Holloway et al., 2000). The Bracon prefer caterpillars of three hosts: Almond moth, greater and lesser Galleria mellonella. Moreover, when the ratio of the number of host caterpillars to the number of females of the parasite is small (2-4:1), the largest number of offspring is produced on the greater and lesser Galleria mellonella and when the ratio is high (10-20:1) the largest numbers are produced on the almond moth (Ovorov et al., 2013). The searching ability and the degree of infestation of the host caterpillars are greatly influenced by the density at which they are kept (Kimsanboev et al., 2013). At a high density of the parasite, a decrease in searching ability is found. In all likelihood, this is the result of the desire of females to avoid re-infection above a certain rate. The mortality rate of the parasite is extremely low and practically no effect on the sex ratio occurred as a result of the asynchrony between the life cycle of the parasite and the host.

The lifespan of adult parasites, first of all, depends on the temperature of the external environment. At normal temperatures, imagines live for 3-5 weeks. An elevated temperature significantly shortens this period and a low one, on the contrary, lengthens it, since in this case the metabolic processes in the insect's body slow down and it is capable of falling into a state of suspended animation or diapause. The lifespan of the Bracon at $3-6^{\circ} \mathrm{C}$ reaches 5 months. In addition to the temperature factor, the lifespan of adult wasps is associated with their feeding at the larval and imago stages. 
In this regard, the purpose of this research was to study the optimal biological parameters of the Bracon when kept in laboratory conditions and to develop a technology for their mass breeding.

Mass production of entomophages for biological protection of cotton will help reduce pesticide load and produce environmentally friendly products. At the same time, with the correct use of biological agents, the frequency of treatments with chemical preparations will decrease to $15 \%$ and an increase in yield can reach up to $20 \%$.

\section{Materials and Methods}

In the presented work, we reviewed the development, viability, temperature of the environment, additional imaginal nutrition, as well as the influence of the age of the laboratory host on the sex ratio of the Bracon. The research was carried out in 2011-2017 at the laboratory of useful arthropods of the Kazakh Research Institute for Plant Protection and Quarantine named after Zh. Zhiembaev and in the Zhetysay biofactory (Maktaaral district, Turkestan region, Republic of Kazakhstan). During the period of these studies, we developed a technology for the mass rearing of the Bracon in laboratory conditions. Today, these technologies are actively used in small biological laboratories for the production of the Bracon to protect crops against Helicoverpa armigera. Statistical processing of the data obtained was carried out using the MS Excel 2016 statistical software package.

\section{Temperature Regime}

Since insects are poikilothermic animals, their body temperature to a very large extent depends on the ambient temperature and all metabolic processes between the body and the environment occur at different temperatures at different rates, the influence of the temperature factor of the environment in the life of insects is very important. In this regard, we carried out experiments to determine the effect of temperature for the optimal development of the entomophage at 25,30 and $35^{\circ} \mathrm{C}$. The temperature and humidity in the thermostat were controlled using a psychrometer installed in the thermostat.

The infection of the host with the parasite was carried out in thermostats with a certain temperature regime, where the relative humidity of the air was maintained at $70-75 \%$. This series of experiments was carried out in six replications. Each replication contained 30 caterpillars and 15 pairs (male and female) of the Bracon. Test tubes with two caterpillars of the greater Galleria mellonella of 4-5 years and one pair of the Bracon (previously fed with $20 \%$ sugar syrup) were placed in desiccators with wet sand at the bottom. In each experiment, observations were carried out in 15 test tubes.
The deaths of Bracon males and females attached to caterpillars were recorded regularly. As they died and egg-laying ceased, the test tubes were removed from the thermostat. Further development of larvae, the formation of cocoons and the emergence of imagines took place outside thermostat under conditions of optimal temperature conditions. During the experiment, we counted the number of eggs, cocoons and emerged males and females of a new generation obtained from females that had laid eggs on the host's body at different temperatures. Besides, we determined the development of pre-imaginal phases (eggs, larvae, pupae, emerged imagines), survival rate, the life expectancy of parental pairs and the sex ratio of the new generation of the Bracon. The Survival Rate (SR) of Bracon males and females was determined using the following formula:

$S R=\frac{a}{b} \times 100$

Where:

$S R=$ The survival rate of the Bracon in \%

$a=$ The number of the Bracon alive on day-, individuals

$b=$ The total amount of the Bracon used in the experiment, individuals

To determine the life expectancy of males and females of the Bracon, the average Life Expectancy (LE) was calculated using the following formula:

$L E=\frac{N_{1} \cdot n_{1}+N_{2} n_{2} \ldots . . N_{n} n_{n}}{N}$

Where:

$L E=$ The average lifespan of a Bracon imago, days

$N_{1}=$ The number of imagines that died per day, individuals

$n_{1}=$ The life expectancy of imagines, days

$n=$ The total number of imagines, individuals

When determining the sex ratio, after the full emergence of the imagines, we took into account the total number of the emerged Bracon, the number of males and females (males and females are distinguished by the structure of the abdomen: There is an ovipositor at the end of the abdominal part of the female's body). The sex ratio $(\mathrm{P})$ was calculated using the following formula:

$P=\frac{p_{1}}{p_{2}}$

Where:

$P=$ The sex ratio

$p_{1}=$ The number of females

$p_{2}=$ The number of males (Zhumaev et al., 2018) 


\section{The Age of the Host}

The greater Galleria mellonella was used as a laboratory host to study the effect of the age of the host on the sex ratio of the new generation of the Bracon.

The experiment was carried out in six repetitions in three variants. For the first variant, caterpillars of the 3rd age were used, for the second, of the 4th age and the third, of the 5th age.

Two individuals of the pest caterpillars were placed in clean test tubes $(175 \times 15 \mathrm{~mm})$ and one pair of Bracon imagines (female and male), previously fed with a $20 \%$ sugar solution, was released there. In each experiment, observations were carried out in 10 test tubes, which were tightly closed with a coarse calico napkin with a pressure band. At the same time, the number of emerged Bracon individuals was recorded, as well as the number of females and males in the offspring.

\section{Results}

To make entomophages used in the biological method of controlling the number of pests bring maximum benefits in production and to decrease the cost of their breeding in biological laboratories, research is required to study the factors affecting their viability, improvement of economically necessary qualities and forming the sex of insects. In this regard, we studied the following factors influencing the development of the entomophage: The influence of environmental factors on the viability and sex ratio of the Bracon; development of preimaginal phases; survival of imagines; life expectancy; sex ratio; the influence of supplementary feeding on the sex ratio of the Bracon; the influence of the age of the laboratory host on the sex ratio of the entomophage.

The Influence of Environmental Factors on the Viability and Sex Ratio of the Bracon (B. hebetor)

\section{The Development of Preimaginal Phases}

In experiments to determine the effect of the temperature regime $\left(25,30\right.$ and $\left.35^{\circ} \mathrm{C}\right)$ on individuals of the parental generation upon infection of the host, we determined such indicators of the developmental biology of an entomophage as the duration of development of eggs, larvae, pupae and the preimaginal cycle of Bracon hebetor as a whole. When adult Bracon individuals were reared in various temperature regimes, the normal development (oviposition, larval stage, pupation and the emergence of imagines) was observed at 25,30 and $35^{\circ} \mathrm{C}$. The dynamics of developmental phases varied markedly. At $38^{\circ} \mathrm{C}$, it was determined that on the $3 \mathrm{rd}$ day, in six experimental samples, all males had died and only in two samples, there were several weakened females, but those, after a day, also died without laying eggs.
At a temperature of $25^{\circ} \mathrm{C}$, the laid eggs were noted by the end of the one-day observation after the replanting of sexually mature individuals to infect the host (the greater Galleria mellonella). After 2-3 days, we observed Bracon eggs, from which larvae hatched. The development of larvae at this temperature lasted 3 to 4 days. Cocoons of the second generation appeared on the 7th day after the start of the experiment or the 6th day after oviposition; the pupal stage lasted 8 to 9 th days. The emergence of single specimens of the daughter generation of the Bracon was noted on the 12 to 17th day, followed by a mass emergence on the 14 to 16th day. The preimaginal developmental cycle lasted 11 to 18 th days.

When the parental pairs and the daughter generation during the preimaginal stage of ontogenesis were kept at a temperature of $30^{\circ} \mathrm{C}$, oviposition happened after 10 to 12th h. The larvae hatched over the next two days. The appearance of cocoons was noted on the 4 to 5 th day from the beginning of the experiment. The pupal stage lasted for 5 to 8th days. On the 9 to 11 th day, after the start of observations, we noted the emergence of single individuals, which ended on the 13th day of the experiment (Fig. 1).

In the fragment of the experiment, where the infection and the preimaginal stage of development of the Bracon took place at $35^{\circ} \mathrm{C}$, oviposition was observed after 5-7 h and the larvae pupated already on the 3rd to 4th day of observation. The emergence of several wasps was recorded on the 7th day and a massive emergence was observed on the 10th day of the experiment.

Thus, experiments with the maintenance of sexually mature wasps at various temperature regimes showed that with an increase in temperature from 25 to $35^{\circ} \mathrm{C}$, the duration of development of larvae, pupae and, consequently, the entire preimaginal phase of the new generation of the Bracon decreased; the developmental cycle of the entomophage accelerated.

\section{The Survival of Imagines}

The determination of the survival rate of imagines of the parental generation after oviposition and keeping the latter throughout the observation period in a thermostat was carried out under the same temperature conditions: 25,30 and $35^{\circ} \mathrm{C}$. The results of the viability of the entomophage, taking into account their survival at different temperatures, are shown in Fig. 2.

Experiments showed that when imagines were kept at a temperature of $25^{\circ} \mathrm{C}$ on the 3rd day of observations, $4.3 \pm 0.4$ males and $1.9 \pm 0.7$ females died out of 15 initial individuals of each sex. On the 5th day of observations, the number of dead males was $5.4 \pm 1.2$ and females $3.9 \pm 1.3$ and on the 7 th day the number of dead males equaled $4.7 \pm 0.9$ and dead females $4.6 \pm 1.3$. The last males $(1.3 \pm 0.6)$ and females $(5.2 \pm 0.8)$ died on the 11 th day of the experiment. 


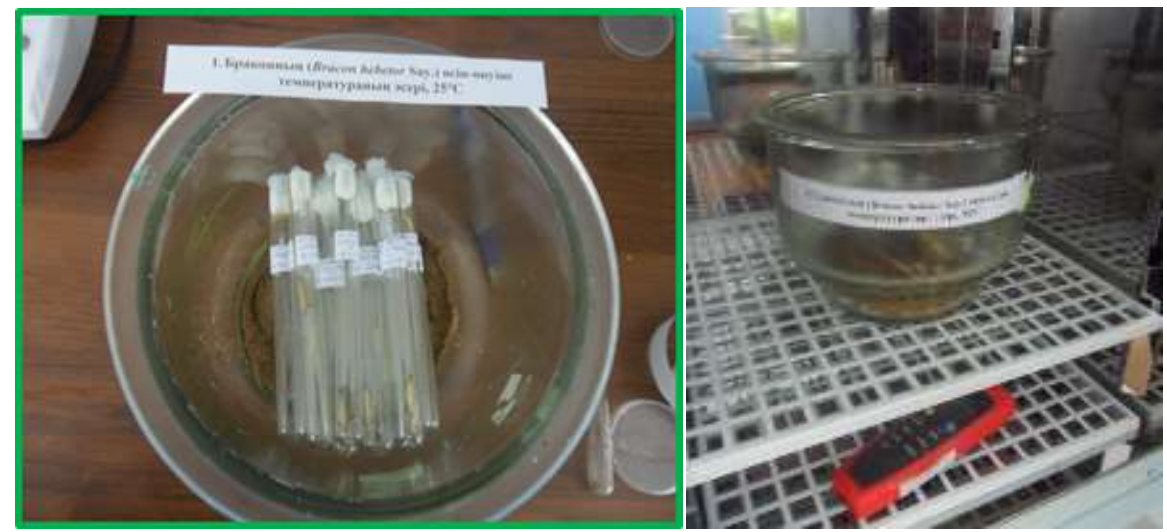

Fig. 1: The breeding of Bracon imagines at a temperature of $25-35^{\circ} \mathrm{C}$ in a thermostat

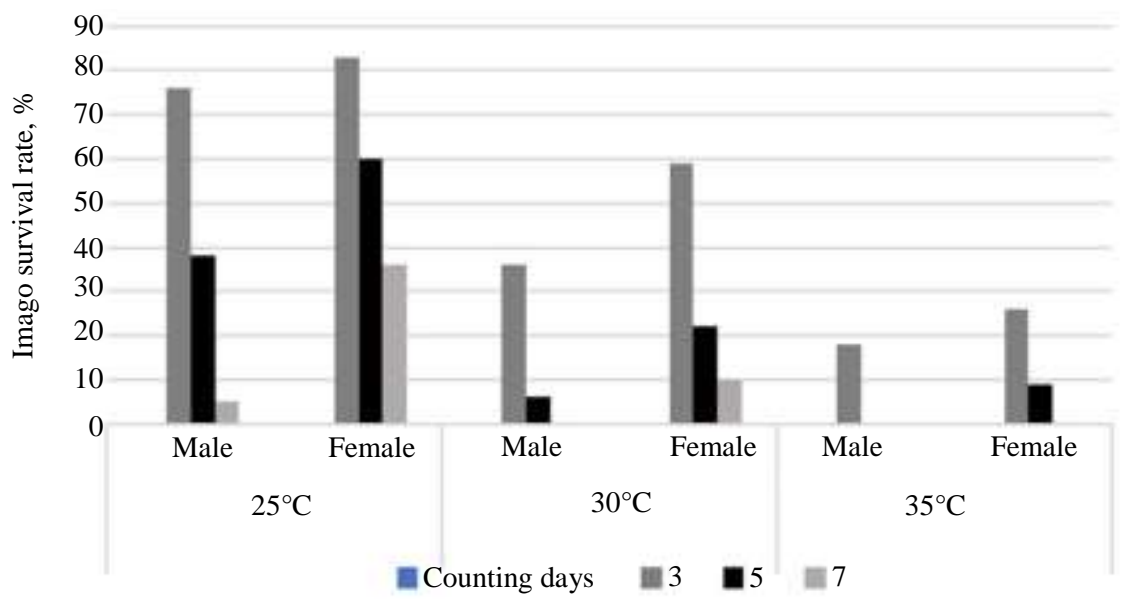

Fig. 2: The effect of different temperatures on the survival rate of the male and female Bracon

At a temperature of $30^{\circ} \mathrm{C}$, a certain pattern was also observed in the dynamics of the survival of males and females. Thus, on the 3rd day after the start of mortality registration, it turned out that out of the original 15 individuals of each sex, 10.8 \pm 0.7 males and $6.6 \pm 1.2$ females died.

The number of males that died on the 5th day of observation equaled $4.3 \pm 1.0$ and that of females $6.0 \pm 0.9$; the remaining $1.0 \pm 0.4$ males died on the 7 th day of observation.

The number of females that died on the 7th day of observation was $0.9 \pm 0.3$.

The death of the remaining females $(1.8 \pm 0.4)$ was recorded on the 11 th day of observation. In this case, although the males had lived for only 7 days and the females for 11 th days, the survival rate of the parental females prevailed in comparison with that of the parental males.

Sexual differentiation in the survival rate of imagines continued to persist even when the imagines of the Bracon were kept at a temperature of $35^{\circ} \mathrm{C}$. In this fragment of experiments, already on the 3rd day of observations, the number of dead males was $13.4 \pm 0.8$ and the number of dead females equaled 10.5 \pm 1.0 . The last $(2.5 \pm 0.7)$ males died on the 5 th day of observation. The number of dead females on the 5th day of observation was $3.3 \pm 0.7$. The last $(1.9 \pm 0.7)$ females died on the 7 th day of observation. Consequently, in this case, females lived somewhat longer than males.

An analysis of the dynamics of the survival rate of the Bracon entomophage shows that this indicator contains sexual differentiation depends on the temperature of the environment where insects are kept. It should be noted that the survival rate of adult individuals of the entomophage decreases as the temperature rises.

\section{Life Expectancy}

The data on the life expectancy of Bracon males and females are presented in Fig. 3. It should be noted that life expectancy in sexually mature individuals of opposite sexes is not the same; in females, it prevails over males. 
As can be seen from the figure, the life expectancy of males and females kept at different temperatures differs and, with an increase in temperature in individuals of both sexes, a tendency for this indicator to decrease appears. The life expectancy of females is longer at all temperature regimes. This indicates a greater resistance of the latter to the effects of environmental factors, including temperature.

Consequently, in such indicators of the viability of the Bracon as survival rate and life expectancy, a strict dependence on sex is manifested, namely: In all temperature conditions, the males used in the experiment died faster than the females. However, sex differences in life expectancy are not expressed to the same extent when experiments are carried out in different temperature conditions. The life expectancy of males, as the temperature increased, decreased sharply, while the females turned out to be more resistant to temperature changes. Although in this case, with an increase in the temperature of their maintenance, their mortality somewhat progressed, in general, the duration of their life throughout the entire observation period was longer than that of males.

Observations of such indicators of the viability of the development of the Bracon entomophage as the ontogeny of the preimaginal phases (the new generation of the Bracon), the survival and lifespan of males and females of the Bracon of the parental generation at temperatures of 25,30 and $35^{\circ} \mathrm{C}$ showed that the rate of development of larvae and pupae and survival rate and lifespan of imagines varied depending on the temperature of the insect. The duration of all the studied phases decreased with increasing temperature, which generally led to a reduction in the life cycle of the Bracon. It should be emphasized that there is a strict sexual differentiation in resistance to temperature effects.

\section{The Sex Ratio}

The upper-temperature threshold for Bracon eggs is $38^{\circ} \mathrm{C}$ and the lower is $15^{\circ} \mathrm{C}$. The optimum temperature for laying is $32-35^{\circ} \mathrm{C}$ at a relative humidity of $70 \%$ (Ismukhambetov, 2011).

To determine the number of females, first of all, we counted the number of cocoons males and females emerged from and then calculated the sex ratio of the emerging generation obtained from females that had laid eggs on the host's body at temperatures of 25, 30 and $35^{\circ} \mathrm{C}$. The observation results are presented in Table 1 .

As can be seen from the table, the fertility of wasps was revealed to be dependent on the temperature regime at which parental pairs were kept during the infection of the host. It is manifested, for example, in such an indicator of fertility as the number of cocoons, which increases with an increase in the temperature at which
Bracon imagines were kept to $30^{\circ} \mathrm{C}$. However, with a further increase in temperature, the positive effect of its effect on the number of cocoons fades away. Thus, the number of cocoons per Bracon female at $25^{\circ} \mathrm{C}$ is $13.8 \pm 0.7$ and that of emerged imagines equals $13.1 \pm 0.5$ individuals; at a temperature of $30^{\circ} \mathrm{C}$ this indicator is $15 \%$ higher than at a temperature of $25^{\circ} \mathrm{C}$ and when insects are kept at a temperature of $35^{\circ} \mathrm{C}$, such an increase is no longer recorded. The number of cocoons per parental pair or female is $16.1 \pm 0.8$ and $15.2 \pm 0.9$ individuals and the number of emerged imagines is $14.7 \pm 0.5$ and $13.6 \pm 1.0$ individuals when the Bracon are kept at a temperature of 30 and $35^{\circ} \mathrm{C}$, respectively. The number of cocoons and emerged wasps when rearing the Bracon at $30^{\circ} \mathrm{C}$ is significantly higher than at $25^{\circ} \mathrm{C}$, while no significant difference in these parameters was recorded when keeping the insects at 25 and $35^{\circ} \mathrm{C}$.

Judging by the number of cocoons and emerged imagines, the greatest viability of insects, regardless of their stage of development, manifested itself when parental pairs were kept at a temperature of $30^{\circ} \mathrm{C}$, i.e., the ability to leave fertile offspring depended on the temperature of the Bracon's habitat.

The results of observations showed that the number of hatched wasps of the offspring depends on the temperature regime of keeping their parental pairs. The largest number of hatching imagines of the Bracon is observed at $30^{\circ} \mathrm{C}$. The parental pairs kept at this temperature give rise to the next generation of imagines, which numerically prevails (by 15 and $10 \%$ ) in comparison with the generation whose parents were kept at temperatures of 25 and $30^{\circ} \mathrm{C}$.

Temperature fluctuations in the maintenance of parental pairs are also reflected in the sexual differentiation of the daughter generation of Bracon hebetor was manifested in a change in the number of females and males.

The number of males to the total number of daughter individuals is 51,33 and $35 \%$ at a parental generation temperature of 25,30 and $35^{\circ} \mathrm{C}$, respectively. If the relative number of males decreases, then the number of females under the same conditions increases, amounting to $49 \%$ in observations using a temperature regime of $25^{\circ} \mathrm{C}, 67 \%$ in experiments with a temperature regime of $30^{\circ} \mathrm{C}$ and $65 \%$ in experiments where mature insects were kept at $35^{\circ} \mathrm{C}$.

Thus, experiments with testing the influence of different temperatures in the process of infecting the host with a parasite on the sex ratio of the entomophage showed that with an increase in the temperature of the parental individuals from 25 to $30^{\circ} \mathrm{C}$, not only fertility increased but also the number of emerged Bracon imagines. With an increase in the number of wasps, we also observed a twofold increase in the number of 
females in the daughter generation. With an increase in the temperature at which the parental pairs were kept up to $35^{\circ} \mathrm{C}$, there was no increase, but, on the contrary, a slight decrease in the emerged wasps was observed.

\section{The Influence of Supplementary Feeding on the Sex Ratio of the Bracon}

Under optimal conditions of keeping the entomophage of the Bracon in the laboratory, we studied the effect of additional imaginal nutrition on the sex ratio of the Bracon entomophage. In this series of experiments, the control individuals were kept without any food and the experimental insects were kept on water, $20 \%$ sugar syrup, protein feed and $20 \%$ honey solution.

Testing of the same feed was carried out in experiments with the study of the effect of additional imaginal nutrition on the sex ratio of the Bracon. The obtained results of experiments carried out in laboratory conditions are presented in Table 2.

It follows from the Table 2 that for any option of additional feeding of imagines, the number of curled cocoons significantly prevails over this indicator in the control group, where imagines were kept without any additional feeding. Thus, fertility in Bracon females, which were kept on drinking water, $20 \%$ sugar syrup, protein feed and $20 \%$ honey solution, respectively, was $1.3 ; 2.9,2.6$ and 3.4 times higher than in the control group.

The observation results showed that the number of the emerged Bracon in all variants of the experiment with the use of additional imaginal nutrition is significantly higher than in the control group, where the insects did not receive any feed. It should be noted that different types of feed affect the number of emerged entomophage individuals differently. Thus, the number of the emerged Bracon from parental couples who had consumed water exceeded the number in the control group by a factor of 1.5. When sugar syrup was used as a feed, the number of emerged Bracon individuals was 4.5 times higher than in the control group. The same tendency was revealed in the case of additional protein feed given to the parental pairs of the Bracon. In this case, the emergence of imagines in the experimental observations was significantly higher (almost 4 times) than in the control observation. The maximum emergence of imagines was observed when a $20 \%$ honey solution was used as feed. At the same time, the observed number of the emerged Bracon was almost 5 times higher compared to the same indicator in the control group.

Consequently, the types of feed used in the experiment have a positive effect on the emergence of the Bracon and this effect has a specific character. The least pronounced effect was found when parental pairs were given water. However, when protein and carbohydrate feed components were used, the emergence of the Bracon increased by a factor of 4-5. Such an increase in the total number of individuals of emerged imagines occurs in both sexes of the Bracon; however, it is not the same in males and females. The number of females that emerged in the first experimental variant, where insects were given water, increased by a factor of 1.9 as compared with the control group; in the second experimental variant, where sugar syrup was used as feed, this increase was by a factor of 5.4; in the third, with protein feeding of parental pairs, the hatching of females increased by a factor of 4.2 as compared to the control group; in the last experimental variant, i.e., when insects were kept on a honey solution, the fecundity of females increased by a factor of 6.2.

It should be emphasized that, even though in all experimental observations the emergence of females prevailed over that of males, the largest number of females, i.e., the highest sex ratio manifested itself when $20 \%$ sugar and honey solutions were used as complementary feed for parental pairs.

Thus, the testing of different options for feeding showed that feeding that was different in quality composition did not equally affect the fertility and sex ratio in the offspring. High fertility was obtained in the experiments using honey and sugar solutions for additional imaginal nutrition. The highest number of females was also obtained by feeding parental pairs with a $20 \%$ solution of honey $(67.2 \%)$ and sugar syrup $(64.5 \%)$.

\section{The Influence of the Age of the Laboratory Host on the Sex Ratio of the Entomophage}

We studied the influence of the age of the host on the sex ratio of the new generation of the Bracon. As a laboratory host of the Bracon entomophage, we used the greater Galleria mellonella (Fig. 4).

The results of experiments on the influence of the size (age) of the laboratory host on the efficiency of Bracon emergence and the ratio of males and females in the offspring are presented in Table 3.

It can be seen from Table 3 that the number of the emerged Bracon, the preimaginal stage of development of which took place on the greater Galleria mellonella, was not the same in all age periods. The number of emerged imagines was 35 and $25 \%$ higher at the 4 and 5 th ages, respectively, compared with the 3rd age of caterpillars. In the sex ratio of the Bracon imago, fluctuations were noted, which were due to the age of the host of the entomophage. Thus, the sex ratio of the Bracon parasitizing in 3rd age caterpillars was 1:1.6, in 4th age caterpillars, it equaled $1: 1.8$ and in 5 th age caterpillars, it was 1:0.9. 


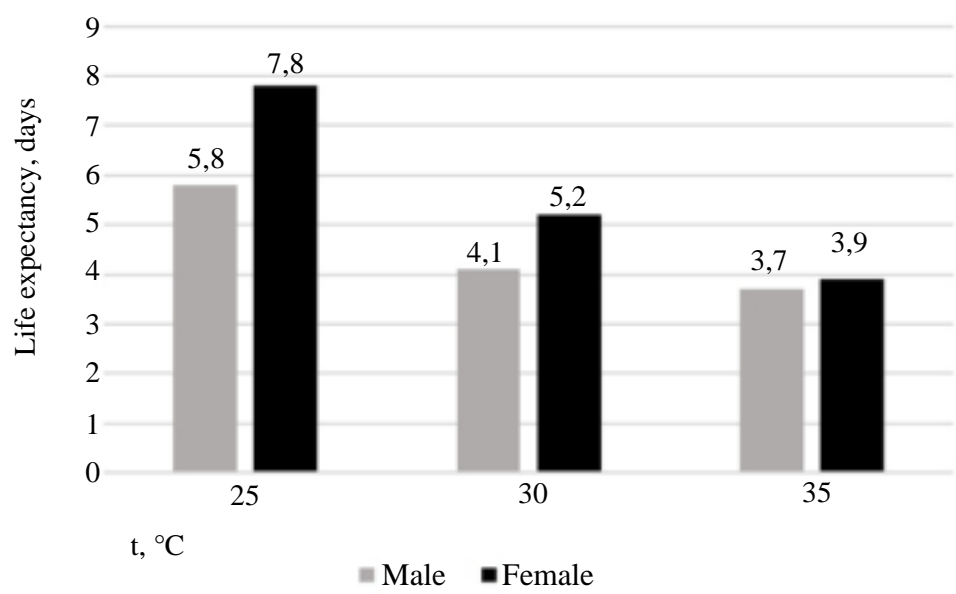

Fig. 3: The life expectancy of the male and female Bracon imagines at different temperatures
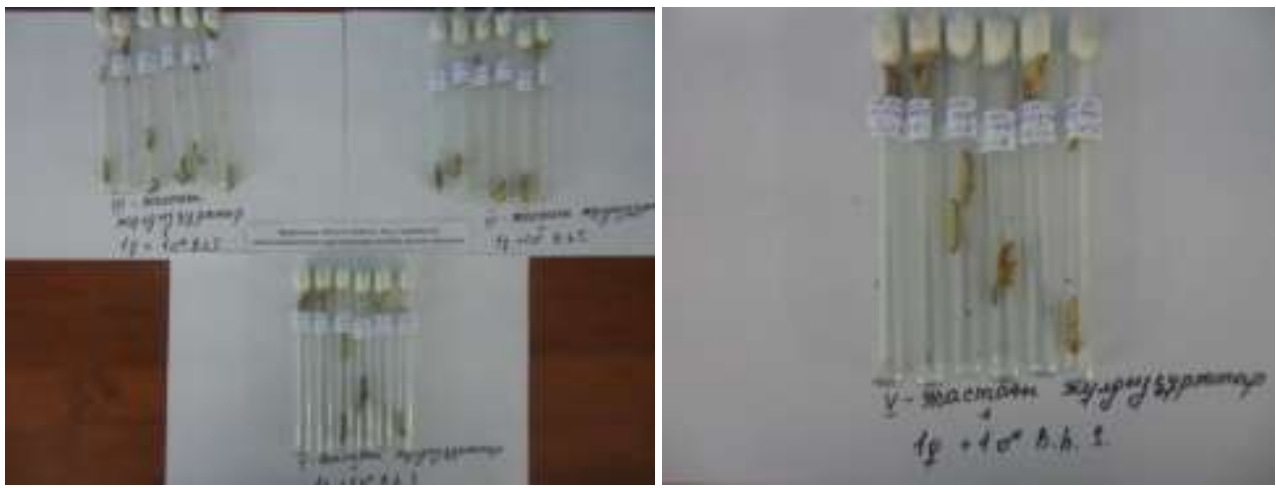

Fig. 4: The experiment to determine the age of the laboratory host: Caterpillars of the greater Galleria mellonella

$\underline{\text { Table 1: Influence of different temperatures on the sex ratio in the progeny of the Bracon }(M \pm m ; n=6)}$

\begin{tabular}{|c|c|c|c|c|c|c|c|}
\hline \multirow[b]{2}{*}{ Temperature $\left({ }^{\circ} \mathrm{C}\right)$} & \multirow{2}{*}{$\begin{array}{l}\text { Number of } \\
\text { Cocoons } \\
\text { (individuals) }\end{array}$} & \multirow{2}{*}{$\begin{array}{l}\text { Number of } \\
\text { wasps emerged } \\
\text { (individuals) }\end{array}$} & \multicolumn{2}{|l|}{ Including } & \multirow[b]{2}{*}{ Sex ratio } & \multirow{2}{*}{$\begin{array}{l}\text { Number of } \\
\text { Bracon cocoons } \\
\text { per parent female } \\
\text { (individuals) }\end{array}$} & \multirow{2}{*}{$\begin{array}{l}\text { Number of the } \\
\text { emerged Bracon } \\
\text { per parent female } \\
\text { (individuals) }\end{array}$} \\
\hline & & & Male (individuals) & Female (individuals) & & & \\
\hline$\overline{25}$ & $200.3 \pm 8.6$ & $180.0 \pm 9.8$ & $92.1 \pm 2.5$ & $87.9 \pm 6.3$ & $1: 1$ & $13.1 \pm 0.5$ & $11.9 \pm 0.8$ \\
\hline 30 & $241.3 \pm 14.2$ & $216.1 \pm 9.7$ & $69.3 \pm 5.6$ & $146.9 \pm 4.3$ & $1: 2$ & $16.1 \pm 0.7$ & $15.0 \pm 0.4$ \\
\hline $\mathrm{P}_{1}$ & $<0.05$ & $<0.02$ & $<0.01$ & $<0.001$ & - & $<0.05$ & $<0.02$ \\
\hline 35 & $226.9 \pm 19.5$ & $201.2 \pm 17.1$ & $72.6 \pm 4.9$ & $129.6 \pm 13.2$ & $1: 1.8$ & $13.9 \pm 1.4$ & $14.2 \pm 0.9$ \\
\hline $\mathrm{P}_{2}$ & $>0.25$ & $>0.5$ & $<0.002$ & $<0.02$ & - & $>0.25$ & $>0.5$ \\
\hline
\end{tabular}

$\mathrm{P}_{1}$ is the reliability of differences between the experiment indicators at a temperature regime of 25 and $30^{\circ} \mathrm{C}$

$\mathrm{P}_{2}$ is the reliability of differences between the experiment indicators at a temperature regime of 25 and $30^{\circ} \mathrm{C}$

Table 2: Influence of different types of feed on the fertility of the Bracon $(M \pm m ; n=6)$

\begin{tabular}{|c|c|c|c|c|c|}
\hline \multirow[b]{2}{*}{ Variants of } & \multirow[b]{2}{*}{ Keeping the Bracon } & \multirow[b]{2}{*}{$\begin{array}{l}\text { Number of the } \\
\text { emerged Bracon } \\
\text { (individuals) }\end{array}$} & \multicolumn{3}{|l|}{ Including } \\
\hline & & & $\begin{array}{l}\text { Male } \\
\text { (individuals) }\end{array}$ & $\begin{array}{l}\text { Female } \\
\text { (individuals) }\end{array}$ & Sex ratio \\
\hline 1. & Control group & $45.7 \pm 4.6$ & $26.1 \pm 3.2$ & $19.6 \pm 1.4$ & $1: 0.8$ \\
\hline \multirow[t]{2}{*}{2.} & Water & $69.8 \pm 9.9$ & $30.3 \pm 4.3$ & $39.5 \pm 5.6$ & $1: 1.3$ \\
\hline & $\mathrm{P}_{1}$ & $<0.002$ & $>0.25$ & $<0.002$ & - \\
\hline 3. & $20 \%$ sugar syrup & $211.8 \pm 8.9$ & $76.7 \pm 4.6$ & $145.1 \pm 4.3$ & $1: 1.8$ \\
\hline \multirow[t]{2}{*}{4.} & Protein feed & $194.5 \pm 12.2$ & $71.5 \pm 6.5$ & $113.0 \pm 5.7$ & $1: 1.5$ \\
\hline & $\mathrm{P}_{3}$ & $<0.001$ & $<0.001$ & $<0.001$ & - \\
\hline \multirow[t]{2}{*}{5.} & $20 \%$ honey solution & $241.3 \pm 10.9$ & $81.2 \pm 5.3$ & $159.1 \pm 5.6$ & $1: 2$ \\
\hline & $\mathrm{P}_{4}$ & $<0.001$ & $<0.001$ & $<0.001$ & - \\
\hline
\end{tabular}

Note: $\mathrm{P}_{1}, \mathrm{P}_{2}, \mathrm{P}_{3}$ and $\mathrm{P}_{4}$ are the reliabilities of differences between the control group and experimental groups $1,2,3$ and 4 
Table 3: Influence of the size (age) of caterpillars of the greater Galleria mellonella on the sex ratio of the Bracon $(\mathrm{M} \pm \mathrm{m}$; $\mathrm{n}=6$ )

\begin{tabular}{|c|c|c|c|c|c|c|c|c|c|}
\hline \multirow[b]{3}{*}{ Laboratory host } & \multicolumn{9}{|c|}{ Age of the host } \\
\hline & \multicolumn{3}{|l|}{$3 r d$} & \multicolumn{3}{|l|}{4 th } & \multicolumn{3}{|l|}{5 th } \\
\hline & $\begin{array}{l}\text { Total, } \\
\text { individuals }\end{array}$ & $\hat{0}$ & q & $\begin{array}{l}\text { Total, } \\
\text { individuals }\end{array}$ & $\hat{\delta}$ & 운 & $\begin{array}{l}\text { Total, } \\
\text { individuals }\end{array}$ & $\hat{0}$ & q \\
\hline Galleria Mellonella & $100.8 \pm 6.2$ & $48.7 \pm 5.2$ & $52.2 \pm 4.7$ & $134.5 \pm 8.7$ & $52.8 \pm 5.2$ & $81.7 \pm 8.7$ & $125.7 \pm 13.4$ & $67.5 \pm 12.1$ & $58.2 \pm 7.3$ \\
\hline
\end{tabular}

The results of the experiment show that the emergence of the Bracon in large numbers was observed when the host had been infected in the older ages (4th and 5th) and the number of females was higher when the host had been infected in the 3rd and 4th ages.

\section{Discussion}

In experiments on keeping parental pairs of the Bracon at various temperature regimes, we studied the following parameters: The viability (development of preimaginal phases, survival, the life expectancy of imagines) and sex ratio of the new generation of the Bracon.

When breeding the Bracon in biological laboratories, first of all, it is necessary to obtain the required number of females in the offspring. The rate of development, survival, life expectancy and sex ratio of entomophages are controlled by the action of various environmental factors. That is why it is necessary to know the nature of the influence of these factors on the developmental biology of the Bracon entomophage, an effective biological agent in the regulation of the number of harmful insects.

The results of the experiment on determining the influence of the temperature regime showed that all stages of the preimaginal development of the entomophage depended directly on the temperature regime at which the Bracon was kept and the rate of development increased with an increase in the temperature of the environment, which was manifested in a reduction in the period of preimaginal development of insects. The temperature regime had a particular effect on the life expectancy and the sex ratio of entomophages. The duration of all investigated phases decreased with increasing temperature, which naturally led to a reduction in the life cycle. Similar results were obtained by (Zhumaev et al., 2018) in the rearing of entomophages (the Bracon and Trichogrammas). In his research, he also studied the effect of temperature on the development of an entomophage. The temperature at which imagines are kept during the process of infecting the host with the parasite is an essential abiotic factor that accelerates the biological time of development of the entomophage, which changes the number of imagines and the ratio of males and females in the daughter generation.
As noted by (Abdullaeva and Yakhyaev, 2015), in the cultivation of the Bracon in laboratory conditions, the role of additional feed of imagines is important in the life span of the parasite and in increasing its reproductive capacity. Although the literature contains some scattered data on this issue and the benefits of one or another type of supplemental feed, a comprehensive test of their effectiveness has not been carried out (Kimsanboev et al., 2007; Nosirova et al., 2018). At the same time, in our experiments, it was revealed that the type of feed also affected the fertility and sex ratio of the Bracon offspring. In our experiments, honey syrup served as the best food for the Bracon imago under laboratory conditions, as many authors, such as (Kimsanboev et al., 2007; Manning et al., 1980; Zhumaev et al., 2018), noted in their works.

The specific features and size of the host, the presence of other parasites in it, the mutual influence of oviparous females are signal factors affecting the sex ratio of Hymenoptera. This diversity of signaling factors plays a role in the mechanisms of sex determination in Hymenoptera. These features create potentially wide possibilities for controlling this mechanism by various external factors perceived by female receptors. Therefore, further research might only expand the set of such stimuli which may be significant both in nature and in mass breeding of entomophages (Alpysbayeva et al., 2018).

\section{Conclusion}

For mass breeding of the Bracon, the most optimal temperature is $30^{\circ} \mathrm{C}$, at which the fertility of the entomophage and the number of females $(67 \%)$ in the offspring increase. At the same temperature, in our experiments, we also noted the largest number of born imagines. Also, the resulting generation predominates by $10-15 \%$ compared to other temperature regimens.

When studying the influence of imaginary nutrition, we found that the maximum emergence of imagines was observed when a $20 \%$ honey solution was used as a feed. At the same time, the observed number of the emerged Bracon was almost 5 times higher compared to the same indicator in the control group.

Caterpillars of the 4th and 5th ages are most suitable for breeding the Bracon. It is explained by the fact that in 
this case, the release of the parasite prevails in comparison with its release during breeding at other ages of caterpillar development.

Using the data of our research, we developed a technology for mass breeding of the Bracon, which is successfully used at the Zhetysay biofactory.

\section{Acknowledgement}

The authors received no financial support for the research.

\section{Author's Contributions}

All authors equally contributed in this study.

\section{Ethics}

This article is original and contains unpublished material. The corresponding author confirms that all other authors have read and approved the manuscript and no ethical issues have been involved.

\section{References}

Abdullaeva, Kh. Z., \& Yakhyaev, Kh. K. (2015). Model "vreditel-entomofag" v biologicheskoi zashchite khlopchatnika $\mathrm{i}$ ee primenenie [The "pestentomophage" model in biological protection of cotton and its application]. NAUKA I MIR, 1 (9(25)):

56-58.

https://elibrary.ru/item.asp?id=24170834

Alpysbayeva, K. A., Sagitov, A. O., Duisembekov, B. A., \& Chadinova, A. M. (2018). Development of the biological method of protecting cotton from pests in South Kazakhstan. Ecology, Environment and Conservation, 24(1), 540-544.

Bogatyrev, O. D., \& Agas'yeva, I. S. (2019). Massovoye razvedeniye entomofaga habrobracon hebetor say: tekhnicheskiyeresheniya, pozvolyayushchiyesnizit' stoimost' konechnoyproduktsii [Mass dilution of the entomophage habrobracon hebetor say: Technical solutions to reduce the cost of the end product]. PlodovodstvoiyagodovodstvoRossii, 59: 207-211. https://doi.org/10.31676/2073-4948-2019-59-207-211

Chanda, S., \& Chakravorty, S. (2000). Morphogenetic derangements in the reproductive system of Bracon hebetor, a beneficial parasitoid, bred on juvenoid treated host (Corcyra cephalonica) larvae. http://nopr.niscair.res.in/handle/123456789/24027

Drozda, V. F., \& Zagaiko, O. I. (2016). Integrirovannaya zashchita tomatov ot listogryzushchikh sovok [Integrated protection of tomatoes against leafeating bollworms]. Zashchita i karantin rastenii, 12: 28-30. http://www.z-i-k-r.ru/anons/dec16/dec16.htm
FiBL, 2015. Sustainability and Quality of Organic Food. FOA. $\quad$ p: $10 . \quad$ https://organicinfo.ua/wpcontent/uploads/2019/10/FiBL_publication_Sustain ability-and-quality-of-organic-products_en.pdf

FiBL, IFOAM, 2015. The World of Organic Agriculture.p: 129 https://www.fibl.org/fileadmin/documents/shop/166 3-organic-world-2015.pdf

Holloway, A. K., Strand, M. R., Black, I. V, W. C., \& Antolin, M. F. (2000). Linkage analysis of sex determination in Bracon sp. near hebetor (Hymenoptera: Braconidae). Genetics, 154(1), 205212. https://www.genetics.org/content/154/1/205

Ismukhambetov, Zh. D. (2011). Puti razvitiya biologicheskogo metoda zashchity rastenii [Ways of development of the biological method of plant protection]. Vestnik selskokhozyaistvennoi nauki Kazakhstana, 5: 3-8. https://elibrary.ru/title_about.asp?id=27234

Kimsanboev, Kh. Kh., Buriev, Kh. Ch., \& KNazarov, Kh. (2013). Brakon bioekologiya sivakopaytirish texnologiyasi [Bracon bioecology and reproduction technology]. Tashkent. pp: 61.

Kimsanboev, Kh. Kh., Sulaimonov, B. A., Rashidov, M. I., \& Boltaev, B. S. (2007). Goza zararkunandalariga qarshibiolaboratoriyalarda hasharotlarni kopaytirish va qollash asoslari [Basics of insect breeding and application in cotton laboratories against cotton pests]. Talkin, Tashkent. pp: 4. https://scholar.google.com/citations?user=uYlkEec AAAAJ \&hl=ru

Kovalenkov, V. G., Tyurina, N. M., \& Pavlova, L. I. (2016). Biologicheskie osobennosti i opyt massovogo razmnozheniya i prakticheskogo primeneniya gabrobrakona (Habrobracon hebetor Say.) [Biological characteristics and experience of mass reproduction and practical application of Habrobracon (Habrobraconhebetor Say.)]. Sbornik trudov konferentsii "Biologicheskaya zashchita rastenii-osnova stabilizatsii agroekosistem" [Proceedings of the conference "Biological plant protection: the basis for stabilizing agroecosystems"], Sept. 20-22, FNBNU "Vserossiiskii nauchno-issledovatelskii institut biologicheskoi zashchity rastenii", Krasnodar, pp: 240-245.

Lamberth, C., Jeanmart, S., Luksch, T., \& Plant, A. (2013). Current challenges and trends in the discovery of agrochemicals. Science, 341(6147), 742-746. https://doi.org/10.1126/science.1237227

Lysov, A. K. (2010). Evropeiskii Soyuz proyavlyaet zabotu o dalneishem ogranichenii ispolzovaniya pestitsidov [European Union is concerned about further limiting the use of pesticides]. Zashchita i karantin rastenii, 4: 16a-16. https://elibrary.ru/item.asp?id=13610688 
Manning, W. J., \& Feder, W. A. (1980). Biomonitoring Air Pollutants with Plants, London: Applied Science Publishers, $\quad$ pp: 2-17. https://www.springer.com/gp/book/9780853349167

Monastyrskii, O. A. (2006). Nuzhny li biopreparaty I biologicheskaya zashchita rasteni i selskomu khozyaistvu? [Are biological products and biological plant protection necessary for agriculture?]. Zashchita rastenii, 11: 6-9. https://elibrary.ru/item.asp?id=9524175

Nagibina, M. N. (2014). Intensifikatsiya selskogo khozyaistva v Rossii [Agricultural intensification in Russia]. Vestnik Rossiiskogo gosudarstvennogo agrarnogo zaochnogo universiteta, 16 (21): 80-82. https://elibrary.ru/item.asp?id=23788857

Narzikulov, M. N. (1982). Integrirovennaya Sistema zashchity khlopchatnika ot vreditelei. Teoreticheskie osnovy i prakticheskie dostizheniya. [Integrated pest control system for cotton. Theoretical foundations and practical achievements]. Vestnik AN SSSR, 5: 20-34.

Nosirova, Z. G., Rustamov, M., \& Bakhromov, B. (2018). Effektivnostprimeneniyaentomofagov v borbe $\mathrm{s}$ nochnyminasekomymi-vreditelyami [The effectiveness of the use of entomophages in the fight against nocturnal insect pests]. Proryvnye nauchnye issledovaniya: problemy, zakonomernosti, perspektivy. X Mezhdunarodnaya nauchnoprakticheskaya konferentsiya [Breakthrough scientific research: problems, patterns, prospects. 10th International research and practice conference], March 18, Nauka i Prosveshcheniye, Penza, pp: 105-108. ISBN: 978-5-907046-83-2.

Ovorov, D.N., Zhivykh, A. V., \& Proskuryakova, M. Yu. (2013). Khlopkovaya sovka-periodicheskaya ugroza selskokhozyaistvennym posevam [Cotton bollworm: a recurring threat to agricultural crops]. Zashchita i karantin rastenii, 5: 18-20. http://www.z-i-kr.ru/ZiKR_2013/ZiKR_05_2013.pdf

Rogozin, M. Yu., \& Beketova, E. A. (2018). Ekologicheskie posledstviya primeneniya pestitsidov $\mathrm{v}$ selskomkhozyaistve [Environmental effects of pesticide use in agriculture]. Molodoi uchenyi, $\quad 25 \quad$ (211): $39-43$. https://moluch.ru/archive/211/51593/
Sagitov, A. O. (2011). Budushchee za biologicheskoi zashchitoi rastenii [Biological plant protection is the future]. Zharshy, 3: 3-7.

Sharmagii, A. K. (2019). Perspektivy ispolzovaniya entomofagov dlya regulirovaniya chislennosti samshitovoi ognevki Cydalimaperspectalis $\mathrm{v}$ usloviyakh yuzhnogo berega Kryma [Prospects for the use of entomophages to regulate the number of the box tree moth Cydalimaperspectalis (Walker, 1859) in the conditions of the southern coast of Crimea]. Biologiya rastenii i sadovodstvo: Teoriya, Innovatsii, 4 (153): https://doi.org/10.36305/2019-4-153-58-67

Svechnikova, T. M. (2019). Analiz mirovogo rynka proizvodstva organicheskoi produktsii [Analysis of the world market for the production of organic products]. Moskovskii ekonomicheskii zhurnal, 8: 326-337. https://doi.org/10.24411/2413-046X-201918082

Toleubayev, K. (2009). Plant protection in post-Soviet Kazakhstan: The loss of an ecological perspective. https://library.wur.nl/WebQuery/wurpubs/379189

Toleubayev, K., Jansen, K., \& Van Huis, A. (2011). From integrated pest management to indiscriminate pesticide use in Kazakhstan. Journal of Sustainable Agriculture, 35(4), 350-375. https://doi.org/10.1080/10440046.2011.562036

Zhuchenko, A. A. (2012). Vyzovy XXI stoletiya mirovoii otechestvennoi prodovolstvennoi bezopasnosti [Challenges of the 21st century to global and Kazakh food security]. Agroprodovolstvennaya politika Rossii, 1:6-9. http://agroprodrf.ru/\%D0\%B0\%D0\%BF\%D0\%BF\% D1\%80-\%E2\%84\%961-2012/

Zhumaev, R. A., Sabirov, S. K., Irgashevaand, N. R., \& Makhmudova, Sh. A. (2018). Vyrashchivanie vidov trikhogrammy (T. Chilonis, T. Evanescens) $\mathrm{v}$ biolaboratorii [Cultivation of trichogramma species (T. Chilonis, T. Evanescens) in the biolaboratory]. Aktualnye problem sovremennoi nauki, $\quad 3 \quad$ (100): $107-111$. https://elibrary.ru/item.asp?id=35245575 